\title{
Analysing local newspaper coverage of murders involving street sex workers
}

\section{Louise Wattis}

To cite this article: Louise Wattis (2020): Analysing local newspaper coverage of murders involving street sex workers, Feminist Media Studies, DOI: 10.1080/14680777.2020.1804975

To link to this article: https://doi.org/10.1080/14680777.2020.1804975

Published online: 19 Aug 2020.

Submit your article to this journal 2

Q View related articles $\widetilde{ }$

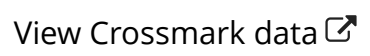




\title{
Analysing local newspaper coverage of murders involving street sex workers
}

\author{
Louise Wattis
}

Department of Humanities and Social Sciences, School of Social Sciences, Humanities and Law, Teesside

University, Middlesbrough, UK

\begin{abstract}
Based on victim hierarchies, news media framing of murdered sex workers is especially pejorative, often shaped by notions of deviant feminine sexuality and sex workers' social and legal marginalisation. The analysis presented in this article explores these themes by focusing on five murders involving young women linked to sex work in a large town in the North of England. It corroborates themes identified in the previous literature relating to shallow and derogatory framing, as well as the way women are reclaimed as victims via the family trope and notions of community. Lastly, the article explores representational tensions in coverage, between acknowledging victimhood and victims' place within their communities, whilst also continuing to Other victims.
\end{abstract}

\section{ARTICLE HISTORY}

Received 3 October 2019

Revised 23 July 2020

Accepted 30 July 2020

\section{KEYWORDS}

Homicide; street sex work; newsprint media

representation; local news

\section{Introduction}

Between 1998 and 2003 in Middlesbrough, a large town in the Teesside region of the North East of England, four young women were murdered, while another woman remains missing, although police suspect she has also been murdered. The cases share commonalities. All victims were linked to street prostitution and problematic drug use. As such, their lives were circumscribed by the disadvantages which so often accompany street sex work in the form of poverty, stigmatisation, and vulnerability (Teela Sanders, Jane Pitcher and Maggie O'Neill 2018). The murders did not gain national notoriety, and for the most part, have remained within the confines of the local imaginary and local news. Three of the cases have not been solved and local news media continue to revisit them at regular intervals, creating a bank of coverage which spans over 20 years.

The following article will explore the systems of representation applied to these murdered young women by analysing local print media. In so doing, it identifies the common motifs news often applies to murdered sex workers, as well as considering how this was filtered through the lens of local/regional coverage. Informed by a feminist position, the article is foregrounded by a recognition that structural conditions shape the murder of women by men (Consuela Corradi, Shalva Weil and Marceline Naudi 2018). Likewise, the ongoing abjection of women linked to prostitution derives from patriarchal constructions of feminine respectability and sexual double standards, whereby it is these women who have historically been

CONTACT Louise Wattis I.wattis@tees.ac.uk Department of Humanities and Social Sciences, School of Social Sciences, Humanities and Law, Teesside University, Middlesbrough, UK 
stigmatised as a result of perceived sexual transgression (Maggie O'Neill 2010; Louise Wattis 2018). Feminist discourse analysis and framing are used to analyse the coverage.

The analysis echoes themes from previous work related to the Othering and blaming of victims and denial of victimhood. However, the coverage analysed spans a twenty-year period from the first disappearance in 1998 (although no articles were available for 1998 and 1999) up to 2018. Because three of the murders remain unsolved, the local press revisits them at regular intervals such as on the anniversaries of murders and disappearances. As such, the longevity of the coverage enables analysis of its evolution as content increased and discourses shifted. Moreover, the focus on local news affords an opportunity to explore how features and conventions unique to local newspapers may shape representations of sex workers as victims.

One final point before proceeding, the terminology used to describe women, sex work, and prostitution is used selectively and sensitively. The stigmatising and political implications of terms such as "prostitute" and "vice girl" (I. Stella 2013) are acknowledged and used only when referencing articles and sources. However, the discussion does refer to "prostitution" as the term is widely used by academics who adopt the sex worker perspective within their research (for example, Sanders, Pitcher and O'Neill 2018).

\section{Previous research: media representations of murdered sex workers}

Patterns in the media's reporting of murder victims linked to prostitution were established in the news coverage of the White Chapel murders of 1888, when five impoverished women were murdered in the east end of London. The perpetrator was never identified, but the case gave rise to the "Ripper myth" and the longstanding cultural fascination with the figure of the male murderer (Lisa Downing 2013). News narratives, which lionised the unknown perpetrator and denigrated victims, set the template for media reporting of similar cases thereafter (Downing 2013; Elyssa Warkentin 2010). The gender dynamics of the Whitechapel murders and their representation at the time, through to the imagining of the Ripper in popular culture and pseudo-criminological analyses reflect powerful gender norms about women's status and disposability in a patriarchal society (Deborah Cameron and Elizabeth Frazer 1987; Warkentin 2010; Louise Wattis 2018). Judith Walkowitz's (1982) examination of the case draws attention to the origins of the now familiar media tropes of titillation, sensationalism, and responsibilisation. She observes for instance, how for the media, the middle classes, and social reformers at the time, the violence itself was overshadowed by widespread anxiety about prostitution as the "great social evil" and the perceived degeneracy and immorality of the victims. Likewise, Warkentin (2010) writes that the murders were viewed as "unfortunate but necessary punishments for deviant female behaviour" (39). It is only recently that victims' lives have been explored in anything like the historical depth and detail applied to the myth of the perpetrator (Hallie Rubenold 2019).

High-profile twentieth Century British cases such as the "Yorkshire Ripper" and the Ipswich murders repeat this representational formula with a "strange uniformity" (Warkentin 2010, 36). Given the newsworthy presence of a serial killer and victims' links to prostitution, press coverage was profligate in both cases. The "Yorkshire Ripper" case, in which Peter Sutcliffe murdered 13 women across the North of England between 1975 and 1980, reveals a police/ media nexus of wholesale misogyny and victim-blaming centred on victims linked to street prostitution. The reciprocal construction of the feminine victim/non-victim by the police and press was especially marked (Downing 2013; Joan Smith, 2013; Wattis 2018). Warkentin's 
analysis of the murder of five young women by Steve Wright in the English city of Ipswich in 2006, also notes the continuation of the well-worn "Ripper" formula. The killer is assigned a moniker, victims are blamed on the basis of their "lifestyle choices" and Othered as "vice girls" and "tarts." Commenting on the case, Juno Mac and Mollie Smith (2018) draw attention to the deeply hostile media commentary on the victims, noting how the case "drew a particularly vicious strain of rhetorical cruelty into the public arena" (90). This is illustrated in the extract below from the Daily Mail:

Another journalist called the five women "disgusting, drug addled street whores" and bridled at what he considered excessive mourning, writing, "We do not share in the responsibility for either their grubby little existences or their murders. Society isn't to blame, death by strangulation is an occupational hazard" (Richard Littlejohn, 2006 cited in Mac and Smith 2018, 90).

More nuanced and sympathetic portrayals of the victims of Steve Wright appeared in the broadsheet press, which reflected on poverty, marginality, and the criminalisation of those involved in street sex work (Warkentin 2010). However, the surfeit of pejorative representations of victims in the cases discussed above, and others involving sex workers (Susan Strega, Caitlin Janzen, Jeannie Morgan, Leslie Brown, Robina Thomas and Jeannine Carriere 2014; Wattis 2018), highlights how the press frequently denies victimhood based on a perceived lack of feminine respectability.

Much of the literature on sex work, victimhood, and representation originates from Canada, written in response to the disappearance and murder of approximately 3000 women in Vancouver and Western Canada over the past three decades (Leyland Cecco 2019). This body of work identifies how legal and media discourses rationalised the victimisation of sex workers by drawing upon the imagery of disease, pestilence, contagion, and disposal (Yasmin Jiwani and Mary L. Young 2006; John Lowman 2000; Strega et al. 2014). The majority of murdered and disappeared women were indigenous and as such, portrayals also relate to Canada's colonial history, the social and economic marginalisation of indigenous peoples and the "sexual governance" of indigenous women (Strega et al. 2014).

In recent years, there has been less academic work looking at news representations of sex workers as homicide victims. That said, work exploring the continuing legal repression and stigmatisation of sex workers continues to identify the role of the media within this (Lynzi Armstrong 2019; Mac and Smith 2018; Teela Sanders 2016). For instance, writing in 2019, Armstrong (2019) maintains that "mainstream media outlets can and do reinforce negative stereotypes and damage sex workers' lives" (1300).

Looking at how media portray other marginalised groups, studies of the framing of migrants and asylum seekers highlight how these groups are also denied legitimacy, both as victims and citizens (Andrea Lawlor 2015; Andrea Lawlor and Erin Tolley 2017). More recent writing focusing on representations of sex trafficking victims across news, documentaries, and awareness campaigns notes similarities and departures from previous work on street sex workers. Responsibilisation and stigmatisation are less evident with victims framed closer to notions of "ideal" victimhood connected to themes of vulnerability and rescue; however, victims of sex trafficking are also represented as lacking in agency (Teresa. C. Kulig and Leah. C. Butler 2019; Kiril Sharapov and Jonathan Mendel 2018).

It has long been recognised that crime news distorts crime realities (Yvonne Jewkes 2013), part of which relates to the construction of myths and hierarchies around victimhood and 
notions of the ideal victim (Nils Christie 1986; Chris Greer 2007). For example, news coverage of male violence against women has its own set of conventions relating to newsworthiness and notions of ideal feminine victimhood. Established literature in this field highlights the visibility/invisibility of victims and acceptance of victim status based on class, victim/offender relationship, feminine respectable femininity, and sexual propriety (Greer 2007; Sue Lees 1996; Maggie Wykes and Kirsty Welsh 2009). More recent studies indicate ongoing issues with coverage of male violence against women: domestic violence is often invisible unless other newsworthy features are present (Michelle Lloyd and Shula Ramon 2017); media remains silent on the structural causes of violence against women and femicide (Corradi, Weil and Naudi 2018); and media reporting of rape retains a preoccupation with victim credibility (Kathryn Royal 2018). Perceived as the "end-point" of feminine anti-respectability (O'Neill 2010), news portrayals of sex workers occupy a particularly extreme place in misogynist news framings of violence against women (Downing 2013; Rubenold 2019).

\section{The lens of local news}

Local news media adheres to a differing set of journalistic conventions to national newspapers (Maxwell McCombs and Marcus Funk 2011). The literature analysing the cultures, conventions, and news agendas of local newspapers emphasises community as integral in shaping the content of regional newspapers. McCombs and Funk (2011) note how demographic and cultural characteristics of local communities determine content, arguing that the regional paper is itself an "expression of local community" (10). For instance, lan Burrell (2014) writes that online regional news sites are deeply local in tone with a big emphasis on sports teams, school exam results, and photographs of school proms, often including user-generated content.

Exploring the state of regional newspapers in an era of global communication technologies, Brett Hutchins (2004) writes that even in the face of globalised networks, which erode our sense of the "local," regional press continues to "speak to a region" (588). In a similar vein, Kristy Hess and Lisa Waller (2012) argue that regional papers are advocates for their local communities, helping to promote "community identity, civic pride and collective involvement" (117). Their analysis of local news coverage, following a series of murders in two rural towns in Australia, showed how local papers defended their localities following negative reporting by national media, and how the community "looked to the local media" (123) to perform this role.

Analysis of local newspaper coverage of the Teesside cases identifies the construction of a problematic locale in terms of crime and street prostitution, alongside a familiar stock set of pejorative framings of street sex workers. However, the analysis also highlights how the local nature of reporting -in terms of the significance of community and the inclusion of victims' families in later reporting-offsets some of the more negative ways in which women linked to sex work were represented in news media.

\section{Methodology}

The corpus was made up of 223 articles; the Newsbank database was used to retrieve articles using the women's names as search terms. The table below presents the number of articles by year. Spikes in coverage mainly relate to developments in investigations and 
anniversaries. Despite the fact that searches did not retrieve any articles for 1998 and 1999, both years are included in the table as Donna Keogh went missing in 1998 and it is significant that no reports appeared where she is mentioned by name until later news coverage, when she is linked to the other cases:

\begin{tabular}{lccccccccccc}
\hline Year & $\mathbf{1 9 9 8}$ & $\mathbf{1 9 9 9}$ & $\mathbf{2 0 0 0}$ & $\mathbf{2 0 0 1}$ & $\mathbf{2 0 0 2}$ & $\mathbf{2 0 0 3}$ & $\mathbf{2 0 0 4}$ & $\mathbf{2 0 0 5}$ & $\mathbf{2 0 0 6}$ & $\mathbf{2 0 0 7}$ & $\mathbf{2 0 0 8}$ \\
Number of Articles & 0 & 0 & 25 & 14 & 33 & 7 & 3 & 6 & 7 & 0 & 2 \\
Year & 2009 & $\mathbf{2 0 1 0}$ & $\mathbf{2 0 1 1}$ & $\mathbf{2 0 1 2}$ & $\mathbf{2 0 1 3}$ & $\mathbf{2 0 1 4}$ & $\mathbf{2 0 1 5}$ & $\mathbf{2 0 1 6}$ & $\mathbf{2 0 1 7}$ & $\mathbf{2 0 1 8}$ & \\
Number of Articles & 2 & 11 & 8 & 16 & 5 & 9 & 9 & 12 & 2 & 52 & \\
\hline
\end{tabular}

Using the Nvivo qualitative analysis package, news articles were coded using a predetermined framework informed by themes from the literature, as well as identifying new categories during the analysis. Prior themes included victim blaming, emphasis on lifestyle and choice, pejorative language, while new coding categories included victim's appearance, emotive language, and the construction of suspects. Informed by critical discourse analysis (CDA), I then used text search functions to explore word occurrences, clusters, and the positioning of words in sentences. In addition, I used the memo and annotation functions in Nvivo to produce analytical reflections from the closer range analysis.

Thematic coding in Nvivo provided the basis for reading texts more closely, drawing on framing and feminist critical discourse analysis (FCDA hereafter). Framing approaches are popular in the scrutiny of media texts (Stephen. D. Reese 2001) and the two approaches are complementary given that myths and frames produce dominant discourses, while textual/linguistic strategies make up the frame (Reese 2001; Teun. A. Van Dijk 1998). For instance, William Gamson and Andre Modigliani (1989) define a frame as an "organising idea" (cited in Reese 2001, 7) and Alain, D. Omrow 2018 contends that "no understanding of critical discourse analysis is complete without reference to framing" (15). Both approaches thus interrogate the value-laden and selective nature of representation (Norman Fairclough, 2003), but CDA focuses on how "prominent patterns of language use" (Omrow 2018, 15) convey the meaning which reproduces ideology, power, and inequality (Fairclough, 2003). FCDA is concerned with ideologies and structures of inequality as they relate to gender (Michelle, M. Lazar 2002). As Emma Dalton (2019) puts it, FCDA focuses on "texts produced in a patriarchal context" (102276).

In regard to the interrogation of language structures as part of CDA, Michelle Sheriff and Ann Weatherall (2009) note the power of "linguistic repertoires," and metaphor in particular, as "cohesive clusters of meaning making" which transmit common sense assumptions and reproduce inequality. Likewise, Ralli Marling (2010) identifies "lexical framing" defined as the repetition of concepts and phrasing with close attention given to the arrangement of words "at the level of sentence" (10). Informed by the literature on CDA and FCDA, a closer reading of the coverage featured in this article, picked up on a range of linguistic strategies deployed by journalists to convey a set of common sense truths about street sex workers, violence, and homicide. The analysis was also alert to silences in the texts, verb structures and choice of verbs and adverbs, sentence structures, word groupings, and the deployment of devices such as hyperbole and modalities (Donna, L. Lillian 2008), as well as the nature and content of headlines.

A brief summary of this analysis illustrates how linguistic arrangements connoted particular givens via the routine use of pejorative language such as "vice girl" and "prostitute" 
across articles, as well as through the frequent, close-range repetition of this terminology in the space of short paragraphs and sentences. Moreover, references to women as victims were often followed by pejorative language. The shift between competing discoursessometimes in the space of a single sentence-often cancelled out victim status and Othered women further. Journalists also achieved this via their frequent use of direct quotations and free indirect speech from friends, family, sex workers, police, and other stakeholders, where unpalatable views could be expressed under the guise of objectivity (Joseph C. Harry 2014).

In addition, a closer analysis of the texts revealed the strategies which rendered male violence against women invisible (see also Ramon and Lloyd 2017) via the use of passive verb constructions. So, for instance, women were murdered, as opposed to men murdering women which excludes the violent male subject from the text. Furthermore, the use of emotive and prurient language to describe violence committed against sex workers distracted from masculinity, violence, and femicide, as well as serving to objectify and sexualise victims and ramp up the melodrama within a voyeuristic framework. Likewise, the use of emotive language in later articles, which were eager to frame young women in a more sympathetic light, made use of idealised language, related to domesticity, family, and childhood to grant women a more "respectable" feminine identity.

\section{Overview of cases}

Twenty-one-year-old Vicky Glass was last seen outside a pub on the outskirts of Middlesbrough town centre in the early hours of the morning of September 24 2001; in early November 2001, her body was discovered in a stream near Danby, a North Yorkshire Moors village, approximately 20 miles from Middlesbrough. In August 2003, police inquiries were ongoing, but the coroner then recorded an open verdict. In May 2002, nineteen-year-old Rachel Wilson also disappeared-last seen on a street in central Middlesbrough; her remains were discovered on farmland to the south of the town in July 2012. The discovery of Rachel's remains prompted a renewed murder investigation into her death, but despite repeated claims from the police relating to new leads and breakthroughs, Rachel's killer is yet to be identified. A case review of the investigation of Donna Keogh's disappearance was completed in August 2016 and a historic inquiry was launched in April 2018 into Donna's suspected murder and the unsolved murders of Vicky Glass and Rachel Wilson (Naomi Corrigan 2018).

Additional two victims make up this series. However, in both cases, suspects were identified and convicted. On September 11 2000, Kellie Mallinson's body was discovered on an industrial estate on the outskirts of Middlesbrough town centre. In 2001, thirty-oneyear-old Shaun Tuley was sentenced to life imprisonment for her murder. In August 2003, George Leigers picked up Sarah Coughlan, took her to his house, and stabbed her repeatedly. He was found guilty of murder and sentenced to life imprisonment which was later reduced to 21 years on appeal by the Criminal Appeal Court on the grounds of diminished responsibility. The police, Sarah's parents and victims' groups challenged the appeal, maintaining that the sentence should reflect the seriousness of the offence and that Leigers remains a threat to the public and should therefore receive a full life sentence (Anne Forbes 2005). In 1986 Leigers had bludgeoned his wife to death but was found guilty of manslaughter and detained in a psychiatric unit for 6 years. In 2006, an independent inquiry concluded that no one was responsible for Sarah's death, even though 
six months prior to murdering Sarah, Leigers was released from psychiatric supervision by the local health authority (Sophie Haworth 2005).

As stated, most coverage derives from local newspapers-in particular, The Evening Gazette, which serves the Teesside area, but also The Northern Echo, the regional paper serving the wider Tees Valley, Durham and North Yorkshire. At particular newsworthy points, however, reports on the murders featured in the national press in The Times, The Sun, The Daily Mail, The Daily Mirror, The Guardian and The Independent, as well local newspapers covering other areas such as The Yorkshire Evening Post. The analysis for this article is based on local news coverage, exploring common themes found in the analysis of the representations of sex workers, as well as considering how "the local" emerged within this corpus of news coverage.

Much of the later coverage focuses on Donna's Keogh-a body has never been recovered; however, the press also returns to the cases of Rachel Wilson and Vicky Glass on the anniversaries of their disappearances. Local media interest has been sustained due to Donna's parents' criticism of the police and their campaign to reopen the investigation, which prompted an apology from Cleveland Police acknowledging investigative failings and a case review in 2016. The discovery of Rachel Wilson's bones on farmland in 2012, 10 years after she had disappeared, and the subsequent reopening of the case was clearly newsworthy for the local press and also appeared in lengthier articles in a number of national and regional newspapers. The launch of an historic police investigation in 2018, focusing on the three unsolved cases of Donna Keogh, Vicky Glass, and Rachel Wilson, reignited press attention-especially as in late June 2018, police launched a search of waste ground for Donna Keogh's body. This accounts for the spike in news coverage to 52 news items in 2018 due to local press reporting on the new investigation and the search for Donna's body.

\section{Analysis}

\section{Inevitable risk in the "red-light underworld"}

Middlesbrough and the wider Teesside conurbation have suffered high rates of joblessness, poverty, ill health, crime, disorder, and problematic drug use as a result of the social and economic decline in the wake of the collapse of core manufacturing in the area (Robert MacDonald and Jayne Marsh 2005). In the late 1990s and early 2000s, street prostitution and "hard" drug markets were especially problematic (Evening Gazette, 2002; MacDonald and Marsh 2005). As stated, the lifespan of news coverage, which forms the basis of this article, continues at the time of writing and reports about the case are interspersed with commentary pieces on the "state" of Middlesbrough during this period, which reflect on crime and other social problems in the town and the Teesside region more widely. Often these commentaries also discussed the murders, setting the cases against the backdrop of crime and illegal markets (Barbera Argument 2004; Naomi Corrigan 2011; Evening Gazette 2002). In the late 1990s into the early 2000s, the local daily paper ran several articles on the "problem" of street prostitution referring to Middlesbrough as a "red-light underworld" and "red-light town." This was informed by the visibility of sex workers in the town centre, as well as evidence that men were travelling from across the North of England to pay for sex (Argument, 2004) - a claim 
borne out by the fact that in 2004, $25 \%$ of all convictions for kerb crawling in England and Wales were dealt with in the Teesside courts (Matt Weaver 2006).

As Costera Meijer (2010) notes, the role of local newspapers is to chronicle local affairs and maintain the collective memory of the regions they cover. Furthermore, writing about rural papers in Australia, Mary Griffiths observes that: "[c]country papers have more direct relationships with their readers because they tend to cover low threshold events that involve local people, places, events and issues that affect their daily lives" (Griffiths, 1998 cited in Hess and Waller 2012,116). This is evident in the way the local daily. The Evening Gazette assumes the voice of the community in expressing concerns over street prostitution on the "streets" of Middlesbrough. Note the headline "Fighting Evil on Our Streets" (Argument, 2004, my emphasis)—where "Our" demarcates community and the problem for said community. Moreover, articles often presented mixed messages, at pains to convey concerns about the murders and the wider backdrop of violence against sex workers, whilst also constructing street prostitution as neighbourhood nuisance in need of tougher policing measures, as highlighted in the extracts below.

In January 2004, a campaign to snare kerb crawlers on Teesside was in full swing. Middlesbrough had gained a murky and unenviable reputation as the North-east's prostitution capital and communities demanded action as vice girls sold sex on residential streets. (Naomi Corrigan 2010)

In the late-1990s the town centre of Middlesbrough was plagued by attacks on young women, many of whom were prostitutes. In 1999, the tide of abuse and violence was seeing a vice girl beaten, raped or robbed every fortnight. Some were murdered. (Corrigan 2018)

The dates of these articles are also telling-2010 and 2018, reinforcing the earlier point about the way in which the local daily revisits "local" issues. For instance, another headline from 2011 asks "What has caused the drop in vice" (Corrigan 2011). These repeated, retrospective commentary pieces on crime and social problems at the local level represent a quintessential feature of this local newspaper coverage. Such repetitive detail and concern with a single locale simply would not feature in the national press.

\section{Normalising and minimising violence against sex workers}

Sanders (2016) argues that violence against street sex work is often viewed as inevitable. My analysis of news coverage also identified how violence against sex workers was frequently normalised. For instance, quotes from sources in articles referred to risks as an "occupational hazard," part of the "culture" and "inescapable." That was often accompanied by the language of victim culpability, where sex work was discussed in terms of "lifestyle" and "choice." The following passage, containing a direct quote from a local outreach project worker, reflecting on the murders and violence against sex workers highlights this: "When something occurs like that there is a strong sense of fear. But they are used to living a dangerous lifestyle" (Corrigan, 2010).

Moreover, these framings obscure the reality of male violence against women by removing the male perpetrator from the frame. In her analysis of representations of missing and murdered women across news and popular culture, Joanne Clarke Dillman (2014) notes something similar, arguing that the "narratives of disappearance" deployed in news coverage minimises what has happened by transferring agency onto the victim so that women go 
missing themselves, as opposed to men killing and taking women. A comparable framing process occurs in the Teesside coverage with some reports speculating that Donna Keogh had fled due to drug debts and Vicky Glass might have "gone off" with a lorry driver.

Another framing device which renders the male perpetrator invisible is a focus on dangerous and risky space. This is illustrated below:

Vicky Glass was among the numerous tragic casualties of Teesside's red-light underworld. In the years surrounding her disappearance, many other girls who turned to prostitution to fund crippling drug addictions were murdered, raped or vanished without trace from Middlesbrough's streets" (Corrigan 2010).

In the extract above Vicky Glass is framed not as a victim of male violence, but as a "casualty" of the "Teesside underworld." The focus on the risky space within the coverage acts to remove the murders from their structural causes-they are not viewed as male violence against women. In a similar way, reports failed to acknowledge economic and social decline as the root causes of the town's problems with poverty, crime, and drugs. Strega et al. (2014) have written about this type of situational distortion in their work on murdered sex workers, arguing that victims are "murdered by men, and their vulnerability to violence turns on race, class and gender stratifications, yet somehow it is the personified 'street' that is designated as responsible" (16). This reflects a general pattern in news representations of violence against women which tends to ignore its systemic nature in the context of patriarchal social relations (Lloyd and Ramon 2017). Furthermore, given that local newspapers are generally weaker when it comes to political analysis (Meryl Aldridge 2007), it is unlikely that analysis of the structural causes underpinning violence against women would feature in coverage. And, to return to the theme of community, given that historically, local papers have a closer relationship with their readers (Aldridge 2007), the local press would likely be reticent to name men from within the community as the problem.

\section{"Prostitute" repetitions and the ideological power of reported speech}

The analysis also reveals how pejorative framing of murdered sex workers is shaped by repeated use of the terms "prostitute," "tart," and "vice girl" (Lizzie Smith 2013; Warkentin 2010). Sex workers and their advocates may use the term, but outside of the sex work community, the term "prostitute" is loaded language given its history as a repressive and stigmatising legal and social classification built around sexual double standards and the singling out of women (O'Neill 2010). Moreover, as Gail Pheterson (1990) highlights, when operationalised within research, the "category prostitute" lacks scientific validity and merely reproduces a range of assumptions and stereotypes about women who sell sex. Indeed, Lizzie Smith (2013) argues that describing a murdered woman as a "prostitute" distances her from "normal," "respectable" women (see also O'Neill 2010), as well as invoking a range of value judgements "about her worth, drug status, childhood, integrity, personal hygiene and sexual health" (N.P.). Likewise, Warkentin (2010) observes how media use of these terms: "simultaneously infantilises and denigrates the women it purports to describe-they are 'girls,' not 'women,' and they are identified as participants in immoral sexual activity" (27). All of which once again obscures the patriarchal sociostructural conditions in which women are killed by men (Corradi et al. 2018). 
News coverage of the Teesside cases reflected this line of representation with frequent reference made to "prostitute," "vice girl" and "drug addict." Moreover, the repetition of labelling language in quick succession, often contained within a single paragraph and beginning with the headline, intensifies the Othering function. Take for instance, the following:

It is irrelevant that she was a prostitute, other than the environment where she worked." Det Supt Dunn made his promise as Marissa, a prostitute friend of Vicky's, appealed for information. He said: "We are extremely anxious to speak to anyone who is a client of a prostitute, prostitutes, themselves, and anyone who visits the Middlesbrough area and uses the overnight lorry park facility at Cannon Park (Durham County Publications 2001).

The above passage illustrates how the repetition of pejorative terminology from a direct source, in this case a police officer working on the investigation, reinforces the negative framing of victims and sex workers. Harry (2014) notes that professional practice demands objectivity from journalists which means the reporter's own opinions and bias should not feature within reports. However, the same objectivity rules do not apply when journalists draw upon "raw opinion and openly persuasive ideologically fuelled rhetoric voiced by news sources, who may be as subjective as they wish" (Harry 2014, 1042). In this way, journalists use reported speech as a means of presenting extreme and unpalatable viewpoints, while seemingly adhering to the "objectivity norm" (Harry 2014, 1055). Moreover, the extract also illustrates the movement between direct and indirect speech-that is the way text "slips" from a direct quote to reported speech (Norman Fairclough 2003) which also reinforces Othering via its reference to "prostitute."

As Aldridge (2007) notes, local papers rely on a set of regular sources, mainly key individuals from police and local government in the "co-production" of local news. The reports analysed here included direct and indirect source content from the police, stakeholders, and friends of murdered women. Indeed, across the 20 years of coverage, source materials derived from victims' families increased and the use of reported speech to reinforce stigma was especially powerful when it came from friends and family. The reporter voice may be unable to state in bald terms- "she was a just a prostitute"; however, this becomes acceptable when expressed by a friend or family member. Or as in the quote below, from a sex worker: "This person could strike again and it could be anyone next, an ordinary woman and not just a prostitute" (The Northern Echo, 2001).

This is further illustrated in the following indirect quote from Vicky Glass' mother. The comment relates to the Ipswich murders and attempts by the local press to link the Teesside cases to the serial murder of five women in Ipswich in 2006: Mrs Goodall said today that she did not think of Vicky as a prostitute-adding that the families of the women in Ipswich would be the same. "They will think of them as daughters, sisters, nieces and granddaughters" (Simon Walton 2008). Again, this demonstrates the slippage from indirect to direct speech, or as Fairclough puts it, the "incorporation" of indirect speech into a "stretch" of direct speech (Norman Fairclough 2003, 55). Harry (2014) argues that indirect speech represents reported source material which is "most semantically distanced-from-an-original-source-utterance ... writer-centred ... more fully in the reporter's control" (1052, his emphasis). In the above example, the author's use of both direct and indirect reported speech is a cynical "revoicing" (Harry 2014) which reinforces Vicky as Other rather than victim. 


\section{The shift to victim status via family relationships}

Nowadays, Deborah prefers to talk about her happier memories of Vicky. It brings tears to her eyes as she shows treasured photos of young Vicky playing with her older sisters and being pushed on a swing by her adoring gran Greta Hart (Corrigan 2010).

This brings me to a discussion of discursive shifts (Carol Smart 1999) in coverage and the increased recognition of murdered women as victims. The switch from "murdered prostitute" to recognised victim occurs as media connects victims to their families (Jiwani et al. 2006). Charting the evolution of Canadian coverage, Strega et al. (2014), observe how media often "recategorised" victims to gain access to their families, as well as in response to activism and pressure from families and victims' groups who demanded women be recognised beyond abject status. Despite this, the authors maintain that blame and culpability still figured in media framing and that often reclamation into families reinforced feminine roles in death. Clarke Dillman (2014) contends that concern for murdered and missing victims expressed in news reports is double edged in that it objectifies women to serve news production agendas where "news coverage is seemingly so intent on showing concern for the girls who have disappeared that it reaches a point of obsession with the dead" (127). Likewise, in the context of this coverage, reports could include the objectified sex worker as victim, whilst also altering the discourse to focus on the tragedy of the murders and the family's anguish.

The foregrounding of family into victims' stories often began with quotes from families featuring in headlines. In addition, and in common with previous work, the representational shifts to victim involved recourse to memories of childhood and early lives as a device to "foreground respectability" (Strega et al. 2014, 15). For instance, reports described the "proud military history" of Donna Keogh's family, while the passage below emphasises Kellie Mallinson's positive character traits and educational success:

Miss Mallinson's mother said her daughter had been led astray into the "murky world" of drugs, and as a child had been popular and clever, leaving Acklam Grange school with a string of high-grade GCSEs to work with computers, but fell under the influence of a teenage boy who led her into drugs. She said "Kellie was a sweet, intelligent girl with a ready smile who was always willing to help" (Durham County Publications 2001).

As the quote at the beginning, this section highlights, articles also included commentary on the "family photograph" as a device to "reinstate" young women into the families, as well as including actual photographs of young women as children or teenagers in school uniforms and bridesmaid dresses. The extract below is taken from an article, which was written following the discovery of Rachel Wilson's remains in 2012, 10 years after her disappearance. The article places Rachel within the family home, amongst her family, referring to photographs of her, alongside other family members: "Pictures of the darkhaired teenager remain dotted around the living room, amidst photos of her siblings, and the nieces and nephews she would never meet" (Lindsay Bruce 2012).

Over the course of two decades of local news coverage, reports on the Middlesbrough cases increasingly emphasised young women as victims, as opposed to foregrounding their culpability in terms of drugs and street prostitution. This type of content still figured but it did "fall away" in later coverage. For instance, early reports on Donna Keogh's disappearance linked her to street prostitution and drug use and speculated that she may have ran away due to drug debts. The most recent reports ceased making these links, possibly due to the 
newspaper's later involvement with Donna's family and their campaign to reopen the investigation into her disappearance. Likewise, in 2001 hard news coverage of Vicky Glass' murder included some input from her family but focused primarily on the police investigation, with a strong emphasis placed on her involvement in street prostitution. In later articles, however, Vicky's family and her early life occupied the foreground. Take for instance this quotation used as a headline from 2010: "When Vicky was born she fought so hard for her life ... whoever killed her snatched it all away."

It is primarily young women's reclamation into the family which grants them victim status; however, their reframing as part of the "community" across the lifespan of the coverage worked in a similar way. For example, The Evening Gazette includes short features entitled Our Say and Your Say. The former is the voice of the paper speaking on behalf of the community (Hess and Waller 2012), offering comment on a range of current and historical stories covered by the paper; in a similar way, the latter is the voice of the community. In 2010 and 2011 Our Say and Your Say revisited the case of Vicky Glass, emphasising the family's grief and appealing for the community to come forward with information to help solve the case. (Evening Gazette, 2010, 2011). The reader's piece was written by a local councillor. It made no reference to drug use or prostitution and, as the following extract highlights, the emphasis is on Vicky as a victim (again via the use of repetition): "In the eyes of the law it doesn't matter what a person does for a living, a victim is a victim and nobody deserves the kind of death meted out to Vicky, herself doubly a victim" (Evening Gazette, 2011).

Drawing on Benedict Anderson's (1983) notions of the imagined community, Aldridge (2007) highlights how being part of the audience/readership of a local paper creates a sense of community. The above examples illustrate how newspapers achieve this by speaking for the community and inviting members to "have their say." "Your Say" calls forth the "community" and brings about young women's acceptance therein. Indeed, the reopening of the cases in 2018 offered the opportunity for individuals to "do their bit" via appeals to come forward with information. This is reflected in several articles featuring Donna Keogh's parents, where they thank the local community for "their ongoing support" (Corrigan $2011,2018)$. The historic investigation into the three unsolved cases and the additional news coverage it generated also granted women additional recognition and legitimacy as victims, as well as further engaging the community. Moreover, the foregrounding of the family acts as a powerful device for community acceptance, as readers are encouraged to identify with victims' families and the press foster relationships with family members.

\section{Discussion}

Literature exploring representations of sex workers has identified a consistent pattern of representation, which objectifies, blames, and responsibilities victims, often drawing on discourses and metaphors of nuisance, disposal, and contagion to rationalise violence against sex workers (Hilary Kinnell 2008; Jiwani and Young 2006; Lowman 2000; Walkowitz 1982; Warkentin 2010). However, several writers note a discursive shift in media representation, whereby dehumanising metaphors fall away somewhat, and victim status is assigned to women via reclamation into the family (Jiwani and Young, 2008; Strega et al. 2014).

My analysis of the print news coverage of five historic murder cases involving sex workers in the town of Middlesbrough in the northeast of England finds similar representational 
consistencies. Reports drew upon familiar tropes of choice and lifestyle, which frame the murders in terms of individual responsibility and culpability, with repetition of "prostitute" labels reducing young women to place holders for a range of negative attributes linked to class, poverty, and deviant femininity. Moreover, the journalistic practice of constructing multivoiced, "quote-based narratives," which combine the voice of the reporter with direct and indirect reported speech from key stakeholders (Harry 2014), emphasises marginal young women as stigmatised subjects under the guise of journalistic objectivity. The analysis also supports previous work which identifies the significance of the family trope in altering representations of victims.

Literature from media studies highlights the local press as advocates for communities, who speak to and for specific regions (Hess et al. 2012; Hutchins 2004; McCombs et al. 2011), with this body of work identifying community and place as integral to the content and news agendas of local newspapers. The findings discussed above evidence consistent representations of sex workers as victims across history and place. However, I also draw attention to themes which are more specific to local news. Namely, community and place, and the role of regional newspapers in speaking for and representing local communities. To take the example of The Evening Gazette, which produced the majority of coverage on the murders, it fits the mould of the local daily, adopting a deeply local tone and covering local sport and human-interest stories with a strong focus on crime (Burrell 2014). The paper evokes a sense of the region's local identity and strives to represent the area positively. Having said that, crime and violence are the lifeblood of local news and the print and online formats of the local paper regularly feature crime stories. This highlights the contradictory position in which local newspapers find themselves. On the one hand, assuming the role of advocate and cheerleader for the local community, while at the same time representing place by way of a range of newsworthy stories depicting violence, drugs, and assorted social problems. Coverage of the Middlesbrough cases reveals these representational tensions, with victims blamed, Othered and placed out with the community, within a wider news narrative relating to drugs, criminal markets, and the problem of street prostitution in the area (Argument, 2004; Evening Gazette, 2002). Victims are then reclaimed via tropes of family and community and make not only the discursive leap from "murdered prostitute" to victim, but also become part of the community rather than a problem for the community (Strega et al. 2014).

Clarke Dillman (2014) argues that popular culture emphasises women's disposability via visual images of dead women, but also notes how media explore women's lives more fully in death, rather in life. As she puts it, women "need to be dead before an exploration of their lives, subjectivities, and experiences is authorised in mainstream representations" (2). Likewise, Strega et al. (2014) argue that "mainstream media cares about street sex workers only under the condition that they are dead" (14). As such, concern for women linked to prostitution following their deaths, expressed by police, media and the wider community remains ambivalent. This article raises further questions about the assignation of victim status and victims' acceptance within the community, highlighting that we must all do better for the marginalised and vulnerable in life, as well as in death. 


\section{Disclosure statement}

No potential conflict of interest was reported by the author.

\section{Notes on contributor}

Louise Wattis is a senior lecturer in criminology at Teesside University. She is interested in gender, victimisation, and representation and has published widely on the representation of sex workers as murder victims. E-mail: I.wattis@tees.ac.uk

\section{References}

Aldridge, Meryl. 2007. Analysing Local Media. Maidenhead: McGraw-Hill.

Argument, Barbera. 2004. "Fighting Evil on Our Streets." The Evening Gazette, April 19.

Armstrong, Lynzi. 2019. "Stigma, Decriminalisation, and Violence against Street-based Sex Workers: Changing the Narrative." Sexualities 22 (7-8): 1288-1308. doi:10.1177/1363460718780216.

Bruce, Lindsay. 2012. "Rachel Begged for Help to Beat the Drug Addiction that Led to Danger." The Evening Gazette, April 19.

Burrell, lan. 2014. “The Dizzying Decline of Britain's Local Newspapers: Do You Want the Bad News or the Good News?" The Independent, August 31.

Cameron, Deborah, and Elizabeth Frazer. 1987. The Lust to Kill. Cambridge: Polity.

Cecco, Leyland. 2019. "Decades of Missing Indigenous Women a 'Canadian Genocide' Leaked Report." The Guardian, May 31.

Christie, Nils. 1986. "The Ideal Victim." In From Crime Policy to Victim Policy, edited by Ezzat Fattah, 17-30. New York: St. Martin's Press.

Clarke Dillman, Joanne. 2014. Women and Death in Film, Television and News: Dead but Not Gone. Basingstoke: Palgrave Macmillan.

Corradi, Consuela, Shalva Weil, and Marceline Naudi. 2018. Femicide across Europe: Theory, Research and Prevention. Bristol: Bristol University Press.

Corrigan, Naomi. 2010. "Vicky Wasn't the Only One - Harrowing Stories of Teesside's Other Tragic Vice Girls." Evening Gazette, September 24.

Corrigan, Naomi. 2011. "What Has Caused the Drop in Vice?" The Evening Gazette, June 10.

Corrigan, Naomi. 2018. "Hunt for Clues in Donna Keogh Inquiry Continues for Fourth Day on Middlesbrough Wasteland." The Evening Gazette, June 21.

Costera Meijer, Irene. 2010. "Democratizing Journalism? Realizing the Citizen's Agenda for Local News Media." Journalism Studies 11(3): 327-42. doi:10.1080/14616700903500256

Dalton, Emma. 2019. "A Feminist Critical Discourse Analysis of Sexual Harassment in the Japanese Political and Media Worlds." Women's Studies International Forum 7 (4): 379-401.

Downing, Lisa. 2013. The Subject of Murder. Chicago: University of Chicago Press.

Durham County Publications. 2001. "No Rest in Hunt for Killer - Pledge." March 18.

Durham County Publications. 2002. "Are These Britain's Worst Streets?" May 16.

Evening Gazette. 2002. "Police target street crime." April 17.

Evening Gazette. 2010. Our Say. 25th September.

Evening Gazette. 2011. Think of the Parent's Pain - Your Say. 26th January.

Fairclough, Norman. 2003. Analysing Discourse: Textual Analysis for Social Research. London: Routledge.

Forbes, Anne. 2005. "Family Blasts Court Farce." The Evening Gazette, March 19.

Gamson, William, A. and Modigliani, A. 1989. "Media Discourse and Public Opinion on Nuclear Power: A Constructionist Approach." American Journal of Sociology 95 (1): 1 ä37.

Greer, Chris. 2007. "News, Media, Victims and Crime." In Victims, Crime and Society, edited by Pamela Davies, Peter Francis, and Chris Greer, 20-49. London: Sage.

Harry, Joseph C. 2014. "Journalistic Quotation: Reported Speech in Newspapers from a Semiotic Linguistic Perspective." Journalism 15 (8): 1041-1058. doi:10.1177/1464884913504258. 
Haworth, Sophie. 2005. "Killing Probe Anger." The Evening Gazette, June 24.

Hess, Kristy, and Lisa Waller. 2012. "'The Snowtown We Know and Love': Small Newspapers and Heinous Crimes." Rural Society 21 (2): 116-125. doi:10.5172/rsj.2012.21.2.116.

Hutchins, Brett. 2004. "Castells, Regional Media and the Information Age." Continuum: Journal of Media and Cultural Studies 18 (4): 577-590. doi:10.1080/1030431042000297680.

Jewkes, Yvonne. 2013. Media and Crime. 2nd ed. London: Sage.

Jiwani, Yasmin, and Mary L. Young. 2006. "Missing and Murdered Women: Reproducing Marginality in News Discourse." Canadian Journal of Communication 31: 895-917. doi:10.22230/cjc.2006v31n4a1825.

Kinnell, Hilary. 2008. Violence and Sex Work in Britain. Devon Cullompton, UK: Willan.

Kulig, Teresa. C., and Leah. C. Butler. 2019. "From "Whores" to "Victims": The Rise and Status of Sex Trafficking Courts." Victims and Offenders 14 (3): 299-321. doi:10.1080/15564886.2019.1595242.

Lawlor, Andrea. 2015. "Framing Immigration in the Canadian and British News Media." Canadian Journal of Political Science 48: 2. doi:10.1017/S0008423915000499.

Lawlor, Andrea, and Erin Tolley. 2017. “Deciding Who's Legitimate: News Media Framing of Immigrants and Refugees." International Journal of Communication 11: 25.

Lazar, Michelle, M. 2002. "Feminist Critical Discourse Analysis: Articulating a Feminist Discourse Praxis." Critical Discourse Studies 4 (2): 141-164. doi:10.1080/17405900701464816.

Lees, Sue. 1996. Carnal Knowledge: Rape on Trial. Harmondsworth: Penguin.

Lillian, Donna, L. 2008. "Modality, Persuasion and Manipulation in Canadian Conservative Discourse." Critical Approaches to Discourse Analysis across Disciplines 2 (1): 1-16.

Lloyd, Michelle, and Shula Ramon. 2017. "Smoke and Mirrors: UK Newspaper Representations of Intimate Partner Domestic Violence." Violence Against Women 23 (1): 114-139. doi:10.1177/ 1077801216634468.

Lowman, John. 2000. "Violence and the Outlaw Status of Street Prostitution in Canada." Violence Against Women 6 (9): 987-1011. doi:10.1177/10778010022182245.

Mac, Juno, and Mollie Smith. 2018. Revolting Prostitutes: The Fight for Sex Workers' Rights. London, UK: Verso.

MacDonald, Robert, and Jayne Marsh. 2005. Disconnected Youth: Growing up in Britain's Poorest Neighbourhoods. Basingstoke: Palgrave Macmillan.

Marling, Ralli. 2010. "The Intimidating Other: Feminist Critical Discourse Analysis of the Representation of Feminism in Estonian Print Media." Nordic Journal of Feminist and Gender Research 18 (1): 7-19. doi:10.1080/08038741003626767.

McCombs, Maxwell, and Marcus Funk. 2011. "Shaping the Agenda of Local Daily Newspapers: A Methodology Merging the Agenda Setting and Community Structure Perspectives." Mass Communication 14 (6): 905-919. doi:10.1080/15205436.2011.615447.

O'Neill, Maggie. 2010. "Cultural Criminology and Sex Work: Resisting Regulation through Radical Democracy and Participatory Action Research." Journal of Law and Society 37 (1): 210-232. doi:10.1111/j.1467-6478.2010.00502.x.

Omrow, Alain, D. 2018. "It Is Not Easy Being Green: A Critical Discourse and Frame Analysis of Environmental Advocacy on American Television." Journal of Media and Communication Studies 10 (3): 14-24. doi:10.5897/JMCS2018.0609.

Pheterson, Gail. 1990. "The Category Prostitute in Scientific Inquiry." Journal of Sex Research 27 (3): 397-407. doi:10.1080/00224499009551568.

Reese, Stephen. D. 2001. "Prologue Framing Public Life: A Bridging Model for Media Research." In Framing Public Life: Perspectives on Media and Our Understanding of the Social World, edited by Stephen Reese, Oscar Gandy, and August Grant, 7-31. Mahwah, NJ: Lawrence Erlbaum.

Royal, Kathryn. 2018. "An Analysis of a High-profile Rape Trial: The Case of UK Footballer Ched Evans." Journal of Gender-Based Violence 3 (1): 83-99. doi:10.1332/239868019X15475689978131.

Rubenold, Hallie. 2019. The Five: The Untold Lives of the Women Killed by Jack the Ripper. London: Transworld Publishers.

Sanders, Teela. 2016. "Inevitably Violent? Dynamics of Space, Governance, and Stigma in Understanding Violence against Sex Workers." Studies in Law, Politics and Society 71: 93-114.

Sanders, Teela, Jane Pitcher, and Maggie O'Neill. 2018. Prostitution: Sex Work, Policy and Politics. London: Sage. 
Sharapov, Kiril, and Jonathan Mendel. 2018. "Trafficking in Human Beings: Made and Cut to Measure? Anti-trafficking Docufictions and the Production of Anti-trafficking Truths." Cultural Sociology 12 (4): 540-560. doi:10.1177/1749975518788657.

Sheriff, Michelle, and Ann Weatherall. 2009. "A Feminist Discourse Analysis of Popular-Press Accounts of Postmaternity." Feminism and Psychology 19 (1): 89-108. doi:10.1177/0959353508098621.

Smart, C. (1999). A History of Ambivalence and Conflict in the Discursive Construction of the 'Child Victim' of Sexual Abuse. Social \& Legal Studies, 8 (3): 391-409. https://doi.org/10.1177/ 096466399900800306

Smith, Joan. 2013. Misogynies: Reflections on Myth and Malice. New York: Fawcett Columbine.

Smith, Lizzie. 2013. "Dehumanising Sex Workers: What's "Prostitute" Got to Do with It." The Conversation, July 29.

Stella, I. 2013. "Language Matters: Talking about Sex Work." Stella, 1-4

Strega, Susan, Caitlin Janzen, Jeannie Morgan, Leslie Brown, Robina Thomas, and Jeannine Carriere. 2014. "Never Innocent Victims: Street Sex Workers in Canadian Print Media." Violence Against Women 20 (1): 6-25. doi:10.1177/1077801213520576.

Van Dijk, Teun. A. 1998. Ideology: A Multidisciplinary Approach. London: Sage.

Walkowitz, Judith. 1982. "Jack the Ripper and the Myth of Male Violence." Feminist Studies 8 (3): 542-574. doi:10.2307/3177712.

Walton, Simon. 2008. "Did Wright Kill Vicky? Officers to Probe Death Similarities." The Evening Gazette, February 25.

Warkentin, Elyssa. 2010. “'Jack the Ripper' Strikes Again: The 'Ipswich Ripper' and the 'Vice Girls' He Killed." Feminist Media Studies 10: 35-49. doi:10.1080/14680770903457097.

Wattis, Louise. 2018. Revisiting the Yorkshire Ripper Murders: Histories of Gender, Violence and Victimhood. Basingstoke: Palgrave Macmillan.

Weaver, Matt. 2006. "Government Cracks down on Kerb Crawlers." The Guardian, January 17.

Wykes, Maggie, and Kirsty Welsh. 2009. Violence, Gender and Justice. London: Sage. 